\title{
Therapeutic Margins in a Novel Preclinical Model of Retinitis Pigmentosa
}

\author{
Richard J. Davis, ${ }^{1,2}$ Chun-Wei Hsu, ${ }^{1,2 \star}$ Yi-Ting Tsai, ${ }^{1,2 \star}$ Katherine J. Wert, ${ }^{1,2,5}$ Javier Sancho-Pelluz, ${ }^{1,2,6}$ \\ Chyuan-Sheng Lin, ${ }^{1,3}$ and Stephen H. Tsang ${ }^{1,2,4}$ \\ ${ }^{1}$ Brown Glaucoma Laboratory, Department of Pathology and Cell Biology, College of Physicians and Surgeons, ${ }^{2}$ Edward S. Harkness Eye Institute, and \\ Department of Pathology and Cell Biology, College of Physicians and Surgeons, ${ }^{3}$ Herbert Irving Cancer Research Center, and ${ }^{4}$ Institute of Human Nutrition, \\ College of Physicians and Surgeons, Columbia University, New York, New York 10032, ${ }^{5}$ New York-Presbyterian Hospital/Columbia University Medical \\ Center, New York, New York 10032, and ${ }^{6}$ Facultad de Medicina, Universidad Católica San Vicente Mártir, Valencia, Spain
}

The third-most common cause of autosomal recessive retinitis pigmentosa (RP) is due to defective cGMP phosphodiesterase-6 (PDE6). Previous work using viral gene therapy on PDE6-mutant mouse models demonstrated photoreceptors can be rescued if administered before degeneration. However, whether visual function can be rescued after degeneration onset has not been addressed. This is a clinically important question, as newly diagnosed patients exhibit considerable loss of rods and cones in their peripheral retinas. We have generated and characterized a tamoxifen inducible Cre-loxP rescue allele, $P d e 6 b^{\text {Stop }}$, which allows us to temporally correct PDE6-deficiency. Whereas untreated mutants exhibit degeneration, activation of Cre-loxP recombination in early embryogenesis produced stable longterm rescue. Reversal at later time-points showed partial long-term or short-lived rescue. Our results suggest stable restoration of retinal function by gene therapy can be achieved if a sufficient number of rods are treated. Because patients are generally diagnosed after extensive loss of rods, the success of clinical trials may depend on identifying patients as early as possible to maximize the number of treatable rods.

\section{Introduction}

Retinitis pigmentosa (RP) is the most common cause of hereditary blindness worldwide (Berson, 1993; Bird, 1995; Klein et al., 1995, 1999; Hartong et al., 2006). Early symptoms include night blindness, rod degeneration, and secondary cone death (Curcio et al., 2000; Owsley et al., 2000, 2001; Jackson et al., 2002). The third-most common cause of autosomal recessive RP is due to loss of rod-specific cGMP phosphodiesterase-6 (PDE6; McLaughlin et al., 1993, 1995; Hanh et al., 1994; Danciger et al., 1995; Dryja and Berson, 1995; Huang et al., 1995; Dryja et al., 1999; Daiger et al., 2007; Dvir et al., 2010). Several mouse models

Received Jan. 29, 2013; revised June 21, 2013; accepted July 11, 2013.

Author contributions: R.J.D. and S.H.T. designed research; R.J.D., C.-W.H., Y.-T.T., K.J.W., J.S.-P., and C.-S.L. performed research; C.-S.L. contributed unpublished reagents/analytic tools; R.J.D., C.-W.H., Y.-T.T., J.S.-P., and S.H.T. analyzed data; R.J.D. and S.H.T. wrote the paper.

Imaging and animal facilities are supported by the NEI Core Grant 5P30EY019007 and NCI Core Grant 5P30CA013696 and unrestricted funds from Research to Prevent Blindness, New York, NY. The Bernard and Shirlee Brown Glaucoma Laboratory is supported by Grant R01EY018213, Department of Defense, Fort Detrick, MD, Grant TS080017-W81XWH-09-1-0575, the Foundation Fighting Blindness, and Joel Hoffman Scholarship, Schneeweiss Stem Cell Fund, Barbara and Donald Jonas Family Fund, Professor Gertrude Rothschild Stem Cell Initiative, and the Tistou and Charlotte Kerstan Foundation. S.H.T. is a member of the RD-CURE Consortium, Fellow of the BurroughsWellcome Program in Biomedical Sciences, and has been supported by the Bernard Becker Association of University Professors in Ophthalmology Research to Prevent Blindness Award, and Dennis W. Jahnigen Award of the American Geriatrics Society.

The authors declare no competing financial interests.

${ }^{*}$ C.-W.H. and Y.-T.T. contributed equally to this work.

Correspondence should be addressed to either Dr Chyuan-Sheng Lin or Dr Stephen H. Tsang, Department of Pathology and Cell Biology, College of Physicians and Surgeons, 635 West 165th Street, Columbia University, New York, NY 10032.E-mail: sht2@columbia.edu.

DOI:10.1523/JNEUROSCI.0419-13.2013

Copyright $\odot 2013$ the authors $\quad 0270-6474 / 13 / 3313475-09 \$ 15.00 / 0$ have been used to study disease progression and develop treatments, including Pde6b ${ }^{r d 1}$, Pde6b $b^{r d 10}$, and Pde6b ${ }^{H 620 Q}$ (Chang et al., 2002; Hart et al., 2005; Gargini et al., 2007). Recent progress using gene therapy in treating PDE6 deficiency has been encouraging (Pang et al., 2008; Davis et al., 2008; Allocca et al., 2011; Petit et al., 2012), especially using a newly developed adenoassociated virus (AAV)8 vector (Petrs-Silva et al., 2009; Pang et al., 2011; Wert et al., 2013).

For several practical reasons, mouse gene therapy is typically conducted by subretinal injection of virus before degeneration. First, efficacy is greatest in mice that do not exhibit early and rapid photoreceptor death. Second, newborns are typically treated because cryoanesthesia, a safer alternative, can be applied (Silva and Gras, 1979; Hirate et al., 1984; Suckow et al., 2012). Third, maturation of the subretinal extracellular matrix can create a barrier to viral spread (Tawara et al., 1989; Blanks et al., 1993; Gruter et al., 2005). As a result, the procedure is technically challenging, can cause trauma, can produce large variance in rescue, and can complicate postdegeneration retinal rewiring (Gargini et al., 2007). Because of these limitations, past experiments have not addressed the clinically important question of whether retinas with grossly advanced disease are treatable. When RP patients are diagnosed, they have midstage disease with peripheral vision loss, and eventually lose central vision, as a result of macular cone degeneration (Tsui et al., 2007; Mitamura et al., 2012). This is particularly important, as a recent report on human gene therapy indicates that despite functional rescue, photoreceptor degeneration continues to progress (Cideciyan et al., 2013). 
A

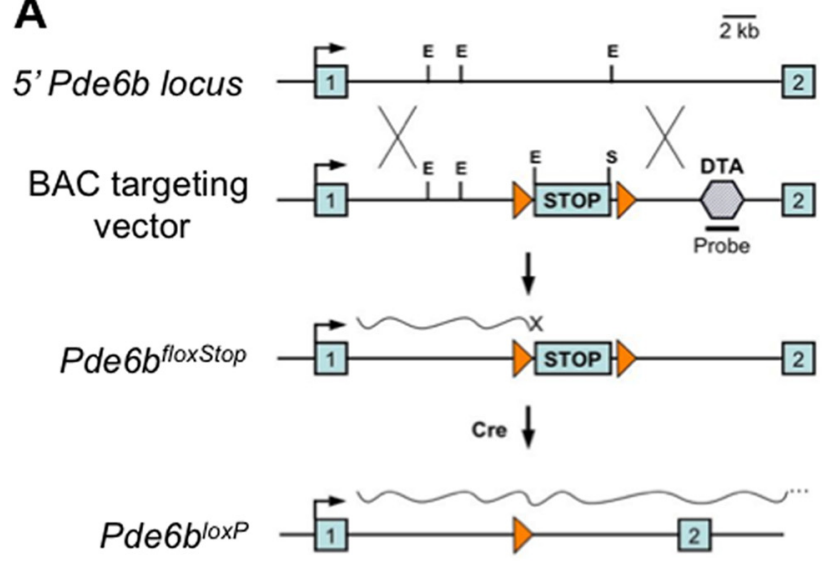

C

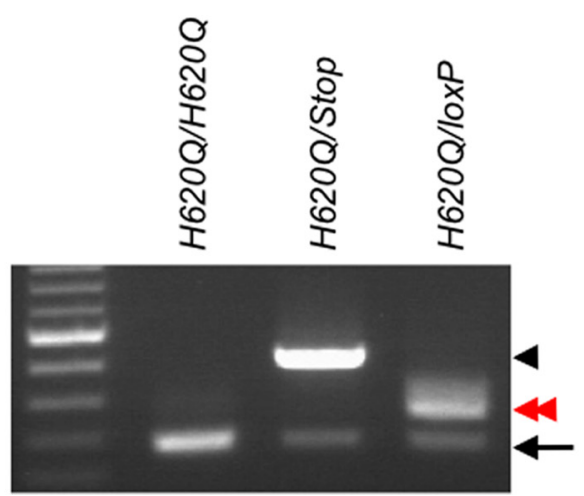

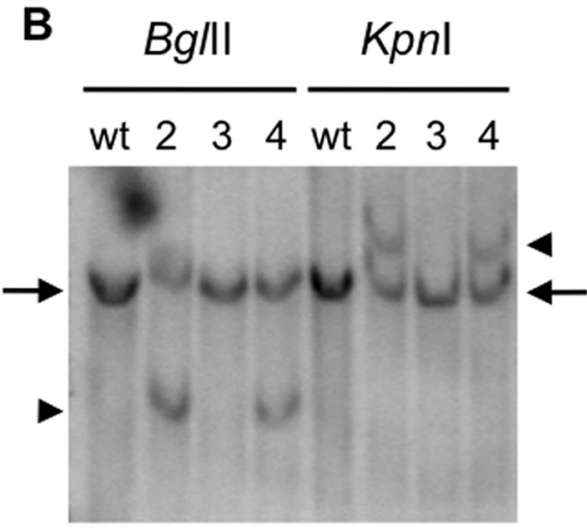

D

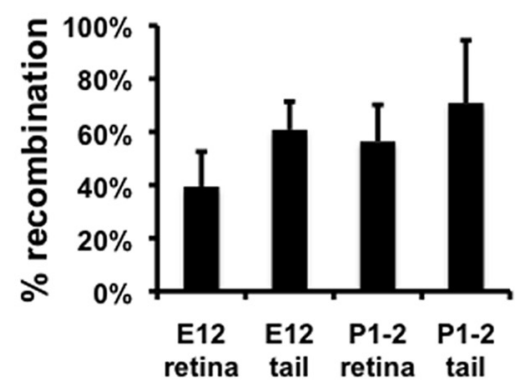

Figure 1. Production of a reversible $P d e 6 b^{\text {Stop }}$ allele, and Cre-mediated generation of $P$ de $6 b^{\text {loxP }} . A$, Scheme for generating the Cre-inducible Pde6 $b^{\text {Stop }}$ allele. Pde6b was targeted with a BAC vector (clone RP23 131C17) containing exons 1 and 2, a floxed Stop/Pgk-neo cassette (loxP triangles flanking STOP), and a DTA-negative selection cassette (hexagon). Homologous recombination places Stop in intron 1 thereby blocking Pde6b expression (wavy line with X). Cre-mediated recombination removes the Stop cassette restoring expression (wavy long line). Recombination was detected in ES cells using a probe sequence that is deleted by introduction of the DTA cassette and is absent in the targeting vector. $\boldsymbol{B}$, Identification of the Pde $6 b^{\text {Stop }}$ allele. Southern analysis of ES cell lines 2 and 4 with an intron 1 probe (not present in targeting vector) detects wild-type (arrows) and recombinant allele (arrowheads) fragments. Line 3 is a nonrecombinant line. C, Cre-mediated recombination detection by PCR. A three-primer assay distinguishes Stop (arrowhead), and loxP (red arrow) alleles within intron 1 (see Materials and Methods). The presence of the $\mathrm{H6200}$ mutation is confirmed by both wild-type sequences in intron 1 and DNA sequencing of exon 15 (black arrow). D, Detection of Stop allele recombination in H620Q/Stop; Rosa26 ${ }^{\text {(reeRT2 }}$ tails and retinas after tamoxifen treatment at E12 or P1-P2 (see Materials and Methods). Percentage recombination is expressed as the amplicon ratio: IoxP/(IoxP + Stop) $\times 100 \%$.

Previous work involved rescuing before degeneration onset in Pde6 mutant mice (Davis et al., 2008; Tosi et al., 2011a,b; Wert et al., 2013). To explore the limits of rescue after degeneration, we generated a model that provides control over the timing of intervention and avoids drawbacks inherent with viral transduction. We have now have tested a novel reversible allele, $P d e 6 b^{\text {Stop }}$, which, in combination with tamoxifen-inducible Cre recombinase (CreERT2), allows us to control when and where rescue occurs. CreERT2 nuclear translocation induces recombination of loxP sites flanking a transcription/translation-inhibitor signal sequences (Stop). When combined with a Rosa26 CreERT2 driver, and exposed to tamoxifen during early embryogenesis, mutant mice exhibited stable long-term rescue. In contrast, tamoxifen exposure later produced either partial long-term or transient rescue.

\section{Materials and Methods}

Mouse lines and husbandry. Pde6b ${ }^{\mathrm{H} 620 \mathrm{Q}}$ mice were derived by oviduct transfer from morulae provided by the European Mouse Mutant Archive (Hart et al., 2005; Davis et al., 2008). Pde6b ${ }^{\text {Stop }}$ mice were generated as

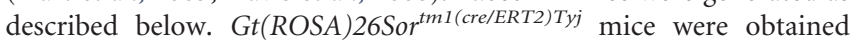
from the Jackson Laboratory. Age-matched C57BL/6J mice were used as standards for testing ERG equipment before use. Mice were maintained in the Columbia University Pathogen-Free Eye Institute Annex Animal Care Services Facility under a $12 \mathrm{~h}$ light/dark cycle. All experiments were approved by the local Institutional Animal Care and Use Committee under protocol AAAF2107. Mice were used in accordance with the Statement for the Use of Animals in Ophthalmic and Vision Research of the Association for Research in Vision and Ophthalmology, as well as the Policy for the Use of Animals in Neuroscience Research of the Society for Neuroscience.

Construction of the Stop targeting vector and generation of Pde6b $b^{\text {Stop }}$ mice. Bacterial artificial chromosome (BAC) recombineering was used to assemble the Stop targeting vector, which was derived from BAC clone RP23 131C17 (Lee et al., 2001). To block Pde6b expression, a floxed Stop cassette was inserted into a nonconserved region of $P d e 6 b$ intron 1 (Lakso et al., 1992). The cassette also contains $P g k-N e o$ for positive selection. To increase the efficiency of generating a correctly targeted, a diphtheria toxin A-chain (DTA) negative selection cassette was added $\sim 2 \mathrm{~kb}$ downstream of the Stop cassette, within the short right homology arm (McCarrick et al., 1993). Within the vector, the DTA cassette replaced $\sim 1 \mathrm{~kb}$ of sequence, which was used as probe for Southern blot screening for homologous targeting events.

To isolate targeted clones, KV1 ES cells (F1 129XB6) were electroporated with $10 \mu \mathrm{g}$ PacI-linearized targeting vector DNA and plated onto mitomycin-treated, neomycin-resistant mouse embryonic fibroblasts (Sancho-Pelluz et al., 2012). The medium was changed $24 \mathrm{~h}$ after electroporation and $150 \mathrm{mg} / \mathrm{ml} \mathrm{G418}$ was added. Ten days later, individual colonies were picked and screened for homologous recombination with the Pde6b locus. Two lines, 2 and 4, were identified and expanded for further analysis. The Pde6b ${ }^{\text {Stop }}$ locus was re-examined by Southern blot analysis and the chromosome content determined by karyotype analysis. 

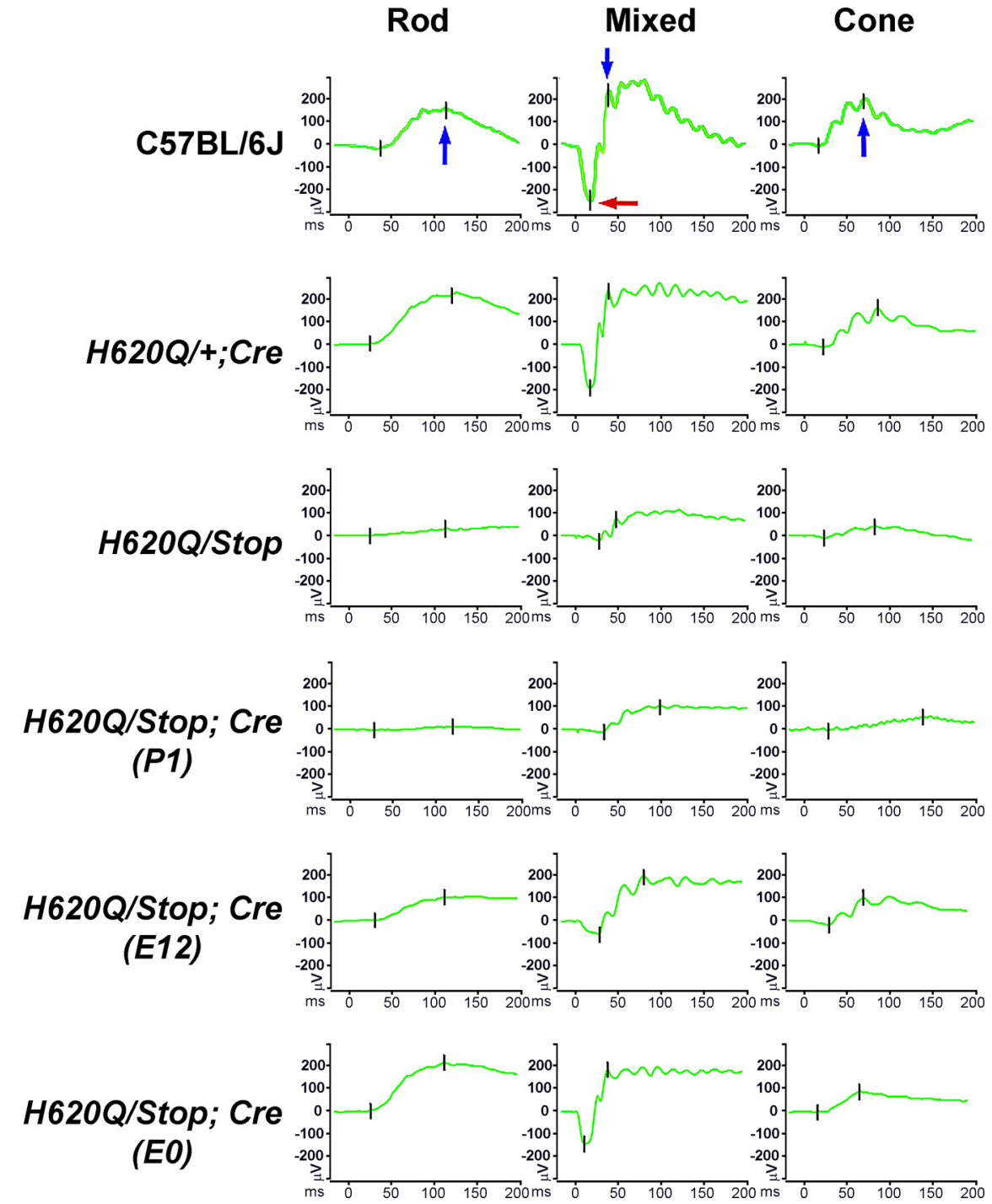

Figure 2. Examples of ERG traces from control and experimental $P d e 6 b^{H 6200} / P d e 6 b^{S t o p}$ mice at 18 weeks. Scotopic rod-specific (rod) and mixed rod-cone (mixed), and photopic cone (cone) responses (green traces). Top panels, blue arrows indicate b-wave peaks, whereas the red arrow indicates an a-wave peak, which is also shown as tick marks. Average peak values were calculated for eye on each mouse as a function of age and combined into the graph shown in Figure 3.

To generate germline chimeras, $10-15$ ES cells from line 2 were microinjected into individual C57BL/6J blastocysts (Tsang et al., 1996). Eight to 10 injected blastocysts were surgically implanted into the uteri of recipient foster mothers. To obtain germline transmission, male chimeras were crossed to $\mathrm{C} 57 \mathrm{BL} / 6 \mathrm{~J}$ females, and progeny evaluated for germline transmission of the $P d e 6 b^{\text {Stop }}$ allele.

Tamoxifen treatment of mice and detection of recombination. To prepare the solution of 4-OH-tamoxifen (Sigma-Aldrich, H7904), $50 \mathrm{mg}$ of tamoxifen was sonicated in $1.5 \mathrm{ml}$ of sunflower seed oil, aliquoted, and stored at $-80^{\circ} \mathrm{C}$. Before use, an aliquot was heated at $60^{\circ} \mathrm{C}$ in preparation for injection. Plug-dated pregnant females carrying H620Q/Stop; Cre+ and control embryos were injected with $1 \mathrm{mg}$ of tamoxifen, to produce E0 or E12 exposed embryos (Danielian et al., 1998; Badea et al., 2003). Alternately, H620Q/Stop; Cre/+ newborns and controls were injected with $\sim 50 \mu \mathrm{g}(\mathrm{P} 1=$ single dose $)$ or $\sim 100 \mu \mathrm{g}(\mathrm{P} 1-\mathrm{P} 2=$ double dose) tamoxifen. For identification of the H620Q allele in exon 15, forward 5' ${ }^{\prime}$-TGCCACGACATCGACCACCG-3' and reverse 5'-GCCATCCCTGCCTTCCCTTGG-3' were created. To distinguish the $P d e 6 b^{\text {Stop }}, P d e 6 b^{\text {loxP }}$, and $P d e 6 b^{+}$alleles in intron 1 , we use a three-primer assay: PDE6B GT-F 5'-TGTGGTGTTGCTCTGCGG TA-3', PDE6B GT-R 5'-ACAAACCTGCACAACCTGCA-3', and PGK-R 5'-GTCCTGCACGACGCGAGCTG-3'.
ERGs. Visual function was evaluated as described previously (Davis et al., 2008; Wert et al., 2013). Mice were dark-adapted overnight, manipulations were conducted under dim red light illumination, and recordings were made using Espion ERG Diagnosys equipment (Diagnosys). Adult C57BL/6J control mice were tested at the beginning of each session to ensure equal readouts from the electrodes for both eyes before testing the experimental mice. Pupils were dilated using topical $2.5 \%$ phenylephrine hydrochloride and $1 \%$ tropicamide. Mice were anesthetized by intraperitoneal injection of $0.1 \mathrm{ml}$ per $10 \mathrm{~g}$ body weight of anesthesia $(1.0 \mathrm{ml}$ ketamine $100 \mathrm{mg} / \mathrm{ml}$ and $0.1 \mathrm{ml}$ xylazine $20 \mathrm{mg} / \mathrm{ml}$ in $8.9 \mathrm{ml} \mathrm{PBS}$ ). Body temperature was maintained at $37^{\circ} \mathrm{C}$ using a heating pad during the procedure. Handmade electrodes were placed upon the corneas and gonioscopic prism solution (Alcon) was applied to each eye. Both eyes were recorded simultaneously. For rod and mixed rod-cone responses, ERGs for dark-adapted mice were recorded using pulses of 0.001 and $3 \mathrm{~cd}-\mathrm{s} / \mathrm{m}^{2}$ (white $6500 \mathrm{~K}$ ), respectively. A total of 20 responses were averaged for each trial. For photopic responses, mice were light adapted in the Ganzfeld dome for at least $10 \mathrm{~min}$. A rod-suppressing steady background of $30 \mathrm{~cd} / \mathrm{m}^{2}$ (white $6500 \mathrm{~K}$ ) was continuously present throughout the trials. ERGs were recorded using pulses of $30 \mathrm{~cd}-\mathrm{s} / \mathrm{m}^{2}$ (xenon). A total of 20 responses (filtered from $0.03-300 \mathrm{~Hz}$ ) were averaged for each trial.

Histochemical analyses. Mice were killed and eyes enucleated as described previously (Davis et al., 2008; Wert et al., 2013). Hematoxylin and eosin (H\&E) retinal sections were prepared by Excalibur Pathology. Quantification of photoreceptor nuclei was conducted on several sections that contained the optic nerve, as follows: the distance between the optic nerve and ciliary body was divided into four quadrants. Three columns of nuclei were counted within each single quadrant. Averages and SDs were calculated from animals for each time-point. Sectioning proceeded along the long axis of the segment so that each section contained upper and lower retina as well as the posterior pole.

Whole retina flat-mount analysis. Mice were euthanized according to established Institutional Animal Care and Use Committee guidelines. Eyes were enucleated and placed in $2 \%$ paraformaldehyde for $1 \mathrm{~h}$ at room temperature. The optic nerve, cornea, and lens were removed. The whole eyecup was then flattened by means of four radial cuts extending out from the optic nerve and mounted with mounting medium (Vectashield, Vector Laboratories). Peanut agglutinin-conjugated Alexa488 staining was accomplished according to the manufacturers instruction (Invitrogen). Visualization was achieved by fluorescence microscopy, and bright-field imaging was used to visualize the whole retina (Leica DM 5000B microscope). Pictures were taken using the Leica Application Suite Software (Leica Microsystems).

Fundus autofluorescence. Imaging was obtained with the Spectralis Scanning Laser Confocal Ophthalmoscope (Heidelberg Engineering). Pupils were dilated, lubricant (GenTeal Liquid Gel, Novartis) was applied to the cornea and body temperature was maintained. The fundus was illuminated with argon laser light ( $488 \mathrm{~nm}$ ) and viewing fluorescence through a bandpass filter with a short wavelength cutoff (495 nm). Detector sensitivity was set between 80 and 100 to avoid pixel saturation. Nine successive frames were acquired in high-speed mode ( 8.9 images $/ \mathrm{s})$ and a $55^{\circ}$ field, and frames were aligned, averaged, and saved in non-normalized mode (Sparrow et al., 2013). 


\section{Results}

Generation of a Pde6b ${ }^{\text {Stop }}$ allele and ${\mathrm{Pde} 6 \mathrm{~b}^{\mathrm{H}}{ }^{20} / \mathrm{Pde} 6 \mathrm{~b}^{\text {Stop }} \text { mice }}$

We designed a gene targeting vector by BAC recombineering using genomic clone RP23 131C17, which contains Pde6b exons 1 and 2 (Fig. 1A). The floxed Stop cassette contains multiple polyadenylation signals in all three reading frames and is designed to prevent gene expression. Cre recombinase activity promotes removal of the cassette and restoration of expression (Lakso et al., 1992). Targeting of Pde6b intron 1 was confirmed by Southern blot analysis using a $3^{\prime}$ genomic probe (Fig. $1 A$ ) and identified two independent ES cell lines: lines 2 and 4 (Fig. 1B).

We then generated $P d e 6 b^{H 620 Q}$ / $P d e 6 b^{\text {Stop }}$ compound heterozygous mice, so that only one Stop allele need be recombined by Cre to efficiently generate $P d e 6 b^{H 620 Q} / P d e 6 b^{\text {loxP }}$ heterozygotes. Additionally, because we expected the Stop cassette to block expression, then Stop/ Stop homozygotes might have a null phenotype which we wanted to avoid. Founders were backcrossed to the $P d e 6 b^{H 620 Q}$ / $P d e 6 b^{H 620 Q}$ strain to produce $P d e 6 b^{H 620} /$ $P d e 6 b^{\text {Stop }}$ mice. H620Q is a partial loss-offunction missense $P d e 6 b$ allele that, in homozygotes, results in severely reduced PDE6 $\beta$ expression and PDE6-specific activity. This leads to rod degeneration that is less severe than in $P d e 6 b^{r d 1}$ mice, but comparable to $P d e 6 b^{r d 10}$ mice (Chang et al., 2002; Hart et al., 2005; Gargini et al., 2007; Davis et al., 2008). A combination of PCR and DNA sequence analyses were used to distinguish wild-type, $P d e 6 b^{H 620 Q}$, and $P d e 6 b^{\text {Stop }}$ alleles during backcrosses and intercrosses (Fig. 1C).

$\mathrm{Pde} 6 \mathrm{~b}^{\mathrm{H} 620 \mathrm{Q}} / \mathrm{Pde} 6 \mathrm{~b}^{\text {Stop }}$ mice exhibit slow progressive photoreceptor degeneration

To measure photoreceptor degeneration in $P d e 6 b^{H 620 Q} / P d e 6 b^{\text {Stop }}$ mice, we used a combination of functional and morphological analyses. Assessment of global retinal function was conducted by measuring scotopic and photopic electroretinogram (ERG) responses between 6 and 18 weeks postnatal (Figs. 2 and 3). Compared with $P d e 6 b^{H 620 Q} / P d e 6 b^{+}$control mice (Fig. 3, blue line), rod-specific b-wave peaks in $P d e 6 b^{H 620 Q} / P d e 6 b^{\text {Stop }}$ mice (Fig. 3, red line) were depressed or extinguished during the times tested (rod b). Similarly, mixed rod-cone responses were lower in mutants and progressively decreased over time ( $\max a, \max b)$. Reductions in photopic cone responses in mutants were slower than rod or mixed rod-cone responses and decreased after 15 weeks (cone b).

We performed a histological analysis of $P d e 6 b^{H 620 Q} / P d e 6 b^{\text {Stop }}$ mutants retinas between 2 and 18 weeks of age. We observed progressive reductions in the number of photoreceptors in the outer nuclear layer (ONL) of $P d e 6 b^{H 620 Q} / P d e 6 b^{\text {Stop }}$ mutants compared with $P d e 6 b^{H 620 Q} / P d e 6 b^{+}$controls (Fig. 4). By 18 weeks, only 1-2 nuclei remain in $P d e 6 b^{H 620 Q} / P d e 6 b^{\text {Stop }}$ mutants, likely comprising cones, as demonstrated by peanut agglutinin staining (PNA; Fig. 5B).

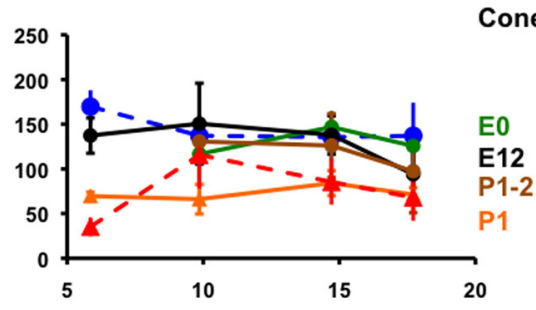

Max b

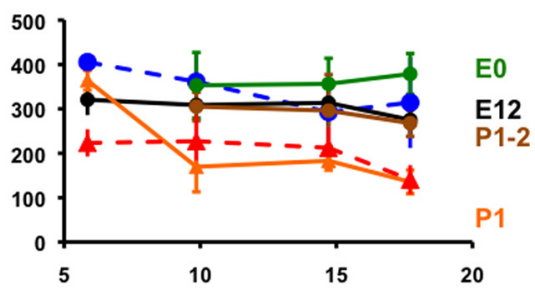

Postnatal Age (weeks)

\begin{tabular}{|c|c|c|c|c|c|}
\hline Weeks & $H 620 Q /+$ & $H 620 Q / S t o p$ & $E 12$ & $P 1$ & $P 1-2$ \\
\hline 6 & 2 & 6 & 20 & 4 & - \\
\hline 10 & 10 & 8 & 14 & 4 & 10 \\
\hline 15 & 8 & 6 & 6 & 4 & 14 \\
\hline 18 & 6 & 6 & 4 & 2 & 4 \\
\hline
\end{tabular}

Figure 3. Rescue of scotopic and photopic function after Stop-loxP recombination. Scotopic rod-specific (rod b) and mixed rod-cone (max a, max b), and photopic cone (cone b) responses in positive control Pde $6 b^{H 620 Q} / P d e 6 b^{+}$(dashed blue) and mutant E0 (green line), E12 (black line), P1 (orange line), and P1-P2 (brown line). Averages and SDs of photoreceptor (a-wave) or inner retina mediated (b-wave) peak intensities are plotted in microvolts on the $y$-axis. Number of eyes assayed is shown in Table 1.

Early Stop allele recombination results in full restoration of retinal function

By using a conditionally active tamoxifen-inducible CreERT2 (Danielian et al., 1998), we have control over the timing of recombination (Brocard et al., 1997; Kellendonk et al., 1999) and can, in principle, restore $P d e 6 b$ expression before or after onset of photoreceptor degeneration. To determine whether removal of the Pde6b Stop cassette can reverse the phenotypic effects of $P d e 6 b^{S t o p}$, we induced Cre recombinase activity during early embryogenesis. The expression driver Rosa26 $6^{\text {CreERT2 }}$ was used as it expresses Cre recombinase widely in many tissues during embryogenesis and into postnatal development (Hameyer et al., 2007).

Pde6b ${ }^{\mathrm{H} 620 \mathrm{Q}} /+$; Rosa26 $6^{\mathrm{CreERT2}} /+$, and Pde6b $\mathrm{H}^{\mathrm{H} 20 \mathrm{Q}} / \mathrm{Pde} 6 b^{\text {Stop }}$ mice were crossed, mothers were injected with tamoxifen shortly after postcoitum (embryonic day 0.5, E0), and progeny were genotyped and analyzed. PCR analysis demonstrated Stop- $>$ loxP conversion in vivo, with the resultant loxP allele readily distinguishable from the unmodified and Stop cassette alleles (Fig. 1C, red arrow). Analysis of retinal function showed similar isolated rod, mixed rod-cone, and cone responses between positive control H620Q/+; Cre+ mice and E0 experimental H620Q/Stop$>$ loxP; Cre/ + mice (Figs. 2 and 3, E0 green lines). Furthermore, there was no detectable evidence of photoreceptor cell loss over the 18 week experiment (Fig. 4).

Varied phenotypic rescue effects after Stop recombination at midembryogenesis or postnatally

To extend our findings, we analyzed the effects of inducing Stop cassette recombination either during mid-embryogenesis (embryonic day 12.5, E12) or postnatally (postnatal day 1, P1). In general, E12 H620Q/Stop->loxP; Cre+ mice showed stronger ERG responses than mutant control H620Q/Stop mice (Figs. 2 and 3 E12 black lines). E12 isolated rod, max, and cone b-wave 

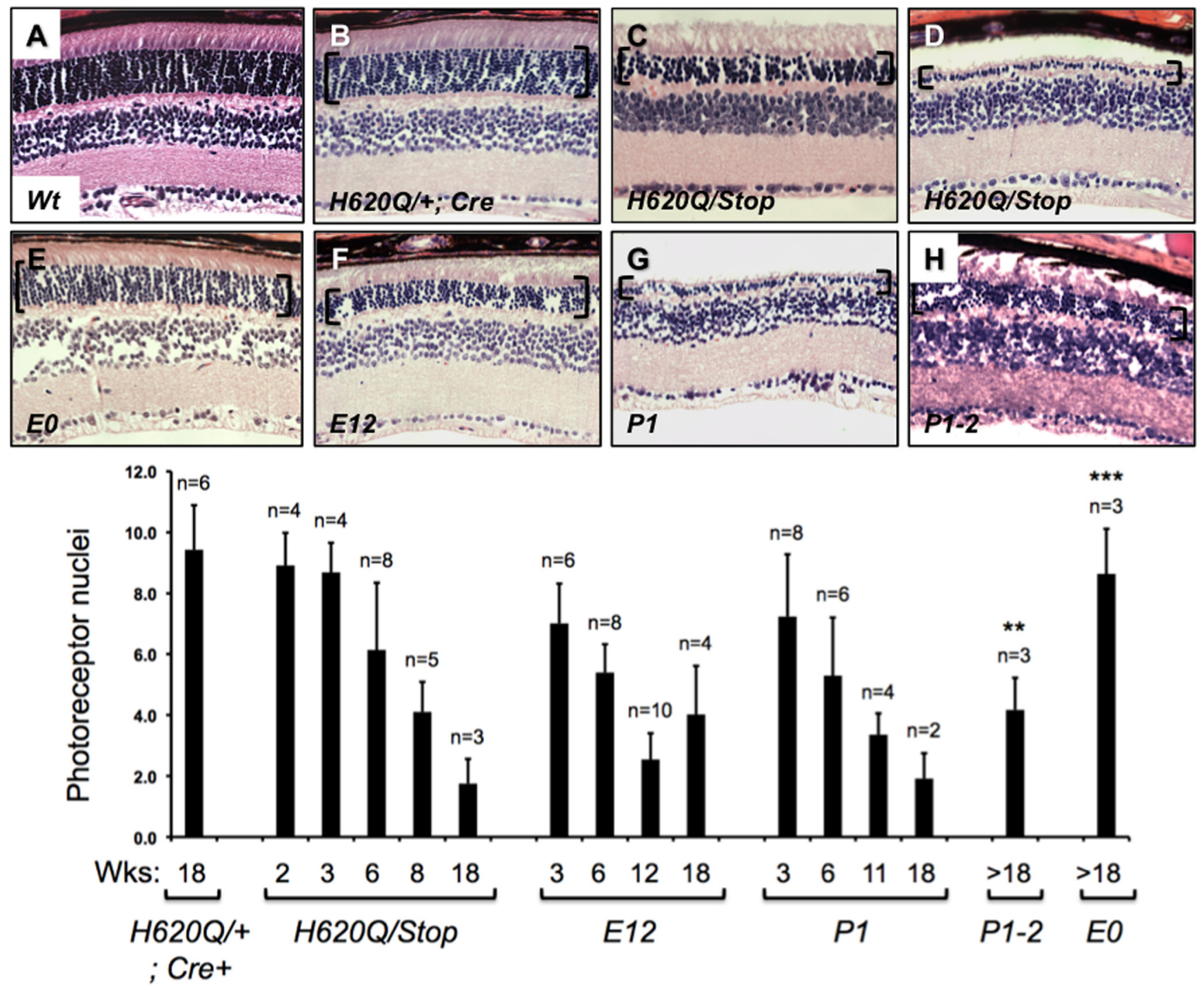

Figure 4. Rescue of $P d e 6 b^{H 6200} / P d e 6 b^{\text {Stop }}$ photoreceptor cells rescue after Cre-loxP recombination. H\&E stained retinal sections from wild-type $(\boldsymbol{A})$, positive control (B), mutant control $(\boldsymbol{C}, \boldsymbol{D})$, and experimental $\mathrm{E} 0$, E12, or P1 mice $(\boldsymbol{E}-\boldsymbol{H})$. All panels are from 18-week-old mice, except $\boldsymbol{D}$, which is from a 9-week-old mouse. The $0 \mathrm{NL}$ is indicated with brackets. $\boldsymbol{F}$, Quantitative analysis of the number of rows of photoreceptor nuclei in histological sections per week. Averages and SDs were calculated from multiple retinas ( $n$ is shown above each column). Unpaired two-tailed Student's $t$ tests were performed on mutant control and experimental data. ${ }^{*} p<0.05,{ }^{* *} p<0.01,{ }^{* * *} p<0.001$.
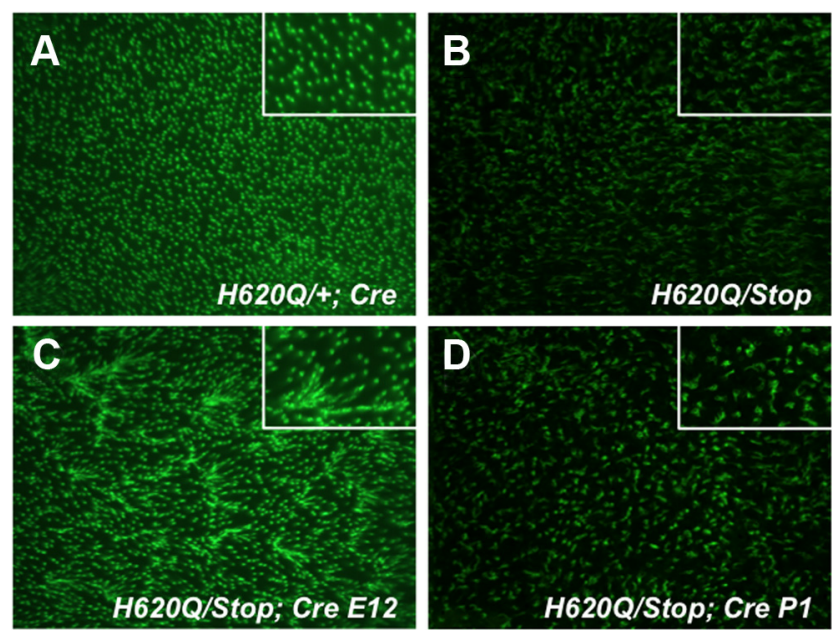

Figure 5. Partial rescue of $P d e 6 b^{H 6200} / P d e 6 b^{\text {Stop }}$ cone dysmorphology. PNA-stained flat mount retinas from 18-week-old positive control $(\boldsymbol{A})$, mutant control (B), experimental E12 (C), and P1 (D) mice. PNA is conjugated to Alexa488. Insets show higher magnification. responses were similar to positive control H620Q/+; Rosa26 $6^{\mathrm{CrEERT2}} /+$ and E0 mice (Fig. 3, compare E12 black to control blue or E0 green lines). Although mixed rod-cone a-wave peaks did not reach positive control levels, these were higher than mutant controls. Finally, there were no signs of progressive degradation of retinal function between 6 and 18 weeks.

In contrast, a single dose of tamoxifen treatment at $\mathrm{P} 1$ failed to produce the strong rescue effects seen at early treatment times (Figs. 2 and 3, P1 orange lines). Although expressed widely in early embryogenesis, the Rosa26-CreERT2 driver may not be active in the postnatal retina (Hameyer et al., 2007). To determine whether the initial test using a single tamoxifen dose was limiting, we provided newborns with a double tamoxifen dose (P1-P2). PCR analysis of retina DNA from E12 $(n=6)$ and P1-P2 $(n=3)$ mice was conducted and detected Stop to loxP alleles recombination occurring at average frequencies of at $39 \%$ and $56 \%$, respectively, suggesting Cre recombinase is actively expressed in retinas (Fig. 1D). To confirm, we monitored photoreceptor function in P1-P2 H620Q/Stop; Cre+ mice and found scotopic rod and maximum a-wave responses were significantly greater in $\mathrm{P} 1-\mathrm{P} 2$ mice 
Table 1. Postnatal Stop recombination results in restored rod photoreceptor function

\begin{tabular}{|c|c|c|c|c|c|c|c|c|c|c|c|c|}
\hline \multirow[b]{2}{*}{ Week } & \multirow[b]{2}{*}{ Control } & \multicolumn{3}{|l|}{ Maxa } & \multicolumn{3}{|l|}{ Rod b } & \multicolumn{3}{|l|}{ Maxb } & \multicolumn{2}{|l|}{$n$} \\
\hline & & P1 & P1-P2 & Control & P1 & P1-P2 & Control & P1 & P1-P2 & Control & P1 & P1-P2 \\
\hline 8 & $-37 \pm 11.4$ & $-36 \pm 7.2$ & $-34 \pm 10.8$ & $51 \pm 29.9$ & $96 \pm 30.7^{*}$ & $140 \pm 37.8^{* * *}$ & $289 \pm 75.7$ & $292 \pm 17.1$ & $357 \pm 43.5^{*}$ & 10 & 4 & 8 \\
\hline 10 & $-36 \pm 8.2$ & $-22 \pm 4.5$ & $-57 \pm 13.6^{* *}$ & $30 \pm 12.5$ & $28 \pm 13$ & $129 \pm 33.9^{* * *}$ & $227 \pm 59.1$ & $170 \pm 56.5$ & $305 \pm 32^{* *}$ & 8 & 4 & 10 \\
\hline 12 & $-28 \pm 8.5$ & $-22 \pm 7.2$ & $-47 \pm 14.2^{* *}$ & $18 \pm 14.5$ & $30 \pm 19$ & $139 \pm 40.6^{* * *}$ & $198 \pm 44.5$ & $197 \pm 48.3$ & $296 \pm 81.2^{*}$ & 8 & 4 & 14 \\
\hline 19 & $-12 \pm 0.1$ & $-18 \pm 4.6$ & $-38 \pm 5^{* *}$ & $14 \pm 6.6$ & $34 \pm 17.8$ & $127 \pm 26.8^{* *}$ & $83 \pm 6.1$ & $136 \pm 26.6$ & $268 \pm 29.8^{* *}$ & 2 & 2 & 4 \\
\hline
\end{tabular}

Comparison of H620Q/Stop mutant mice (control) to newborn experimental (P1 and P1-P2) mice treated with tamoxifen (see Materials and Methods). Double-dose treatment (P1-P2) produces effective and sustained rescue of rod photoreceptor function. Unpaired two-tailed Student's t tests were performed on mutant control and experimental data. ${ }^{*} p<0.05,{ }^{* *} p<0.01,{ }^{* * *} p<0.001$.

than mutant or P1 mice (Fig. 3 P1-P2 brown line; Table 1). In addition, the $\mathrm{P} 1-\mathrm{P} 2$ functional responses were similar to E12 treated mice: although rescue was sustained over the 18 weeks, full restoration of retinal function was not obtained as compared with E0 treatment. Together, these results indicate that CreERT2 recombinase can be activated in the embryonic retinas and postnatal rod photoreceptors.

Full or partial functional restoration of rod and max responses in E0 or E12 and P1-P2 mice suggests preservation of photoreceptors numbers. Histological analysis of E0 mice and control mice showed similar numbers of photoreceptors at $>\mathrm{P} 18$ of age $(8.6 \pm 1.5$ and $9.5 \pm 1.6$, respectively; Fig. 4). In contrast, both E12 and $\mathrm{P} 1$ mice showed a decrease in photoreceptors leading up to week 18 (Fig. 4). E12 mice showed a suggestion of rescue on photoreceptors at P18 (E12: $4.0 \pm 1.6$ vs mutant $1.8 \pm 0.81, p=0.054)$, whereas P1 cell numbers were similar to mutants at P18 (P1: $1.9 \pm 0.83$ vs mutant $1.8 \pm 0.81$, $p=0.76)$. In contrast, partial rescue of photoreceptors was observed in $\mathrm{P} 1-\mathrm{P} 2$ mice $(4.2 \pm 1.1$ vs $1.8 \pm 0.81, p=0.007)$. Because rods die earlier than cones in Pde6b mutants, most of the missing photoreceptors are not likely to be cones, as demonstrated by detection of similar numbers of PNA-stained cones in all samples at 18 weeks (Fig. 5). Despite the loss of rods, those remaining are clearly functional in E12 and P1-P2 mice, compared rods in P1 mice (Fig. 3; Table 1).

During the PNA staining analysis, we noted differences in the appearance of the cones between experimental and control samples. Comparison of positive and mutant control flat mounts demonstrated an abnormal PNA staining in the mutant retinas (Fig. $5 A, B$ ). Instead of small, round punctate shape (Fig. $5 A$, inset), mutant control cones showed a distinct trailing edge/ringshaped shape, reminiscent of a flame (Fig. $5 B$, inset). Unexpectedly, we observed the E12 PNA-staining pattern to consist of a mix of clustered groups of either small cones or flame-like cones (Fig. 5C, inset). In addition, abnormal E12 cones appeared smaller than abnormal cones in the mutant controls. The differences between E12 and mutant control cones cannot be explained by the presence of Cre or tamoxifen treatment, as P1 experimental samples showed a PNA-staining pattern indistinguishable with the mutant controls.

Rescue of an abnormal hyper-autofluorescent fundus pattern We examined control and experimental retinas by fundus autofluorescence, which detects accumulations in A2E fluorophores in the retina. Wild-type and positive control H620Q/+; Cre+ mice showed a diffuse, homogeneous fluorescence pattern (Fig.
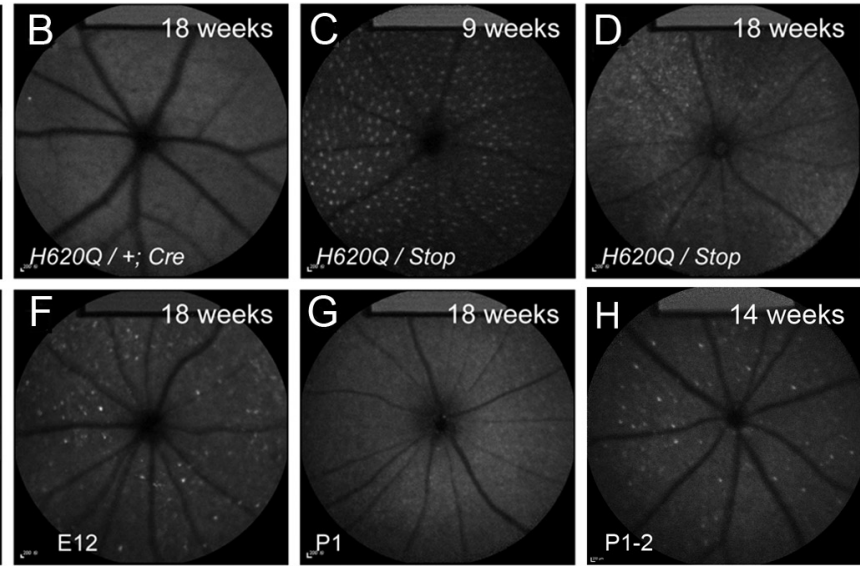

E12
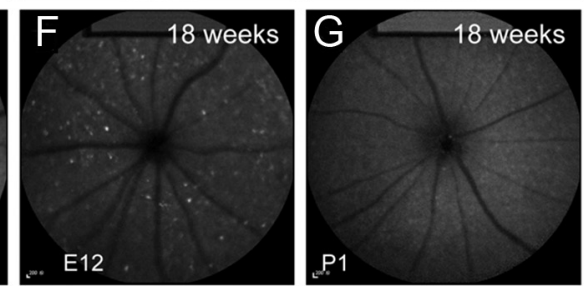

$P$ Figure 6. Partial rescue of $P d e 6 b^{H 6200} / P d e 6 b^{\text {Stop }}$ fundus autofluorescence phenotype. Fundus images from $C 57 \mathrm{BL} / 6 \mathrm{~J}$ control
$(\boldsymbol{A})$, positive control $(\boldsymbol{B})$, mutant control $(\boldsymbol{C}, \boldsymbol{D})$, and experimental E0, E12, P1, or P1-P2 mice $(\boldsymbol{E}-\boldsymbol{H})$. All panels are from 18-weekold mice, except $\boldsymbol{C}$, which is from a 9-week-old mouse.

$6 A, B)$. In contrast, at 9 weeks, mutant control H620Q/Stop mice showed small hyper-autofluorescence (hyper-AF) spots distributed with regular uniformity over the fundus (Fig. 6C). At 18 weeks, this pattern resolves into a confluence of hyper-AF patches of heterogeneous size (Fig. 6D). Because hyper-AF is a secondary consequence of photoreceptor degeneration (Robson et al., 2008; Xu et al., 2008; Lima et al., 2009, 2012; Greenstein et al., 2012), we expected to observe rescue of the mutant hyper-AF pattern after Stop recombination. Indeed, 18-week-old E0 experimental animals showed a similar pattern as positive control mice with no detectable hyper-AF spots (Fig. 6E). In contrast, 18-week-old E12 and $\mathrm{P} 1-\mathrm{P} 2$ mice demonstrated hyper-AF pattern similar to the 9 -week old mutant controls, but with spots of heterogeneous size and nonuniform distribution (Fig. $6 F, H$ ). P1 mice exhibited a fluorescence pattern similar to the mutant controls (Fig. 6G).

\section{Rescue of arteriolar attenuation}

Wild-type and positive control H620Q/+; Cre+ mice showed vessels of normal caliber (Fig. 6A,B). Mutant control H620Q/ Stop mice demonstrated arteriolar narrowing, which progressively worsened between 9 and 18 weeks (Fig. 6C,D). Whereas 18-weekold E0 experimental animals exhibited a similar vessel dimension as positive controls (Fig. 6E), 18-week-old E12 and P1-P2 mice demonstrated partial arteriolar attenuation similar to the 9-week-old mutants (Fig. 6F, H), and single dosing at P1 did not rescue arteriolar attenuation (Fig. 6G).

\section{Discussion}

We have tested a novel reversible allele, $P d e 6 b^{\text {Stop }}$, which in combination with tamoxifen-inducible Cre, allows us to control photoreceptor rescue without surgical trauma associated with delivery of viral gene therapy vectors. We have shown that untreated $P d e 6 b^{H 620 Q} / P d e 6 b^{\text {Stop }}$ mice exhibit a photoreceptor degen- 
eration phenotype that is slower than $P d e 6 b^{H 620 Q}$ homozygous mice (Hart et al., 2005; Davis et al., 2008). When used with Rosa2 $6^{\text {CreERT2 }}$, and exposed to tamoxifen during early embryogenesis, $P d e 6 b^{H 620 Q} / P d e 6 b^{\text {Stop }}$ mice exhibited full and stable rescue of photoreceptor numbers and retinal function. Recombination at later times, during mid-embryogenesis and postnatally, could generate partial rescue of retinal function associated with limited photoreceptor degeneration.

The Stop allele was designed to terminate gene expression (Lakso et al., 1992). We originally expected $P d e 6 b^{H 620 Q} / P d e 6 b^{\text {Stop }}$ mice to have a phenotype at least as strong as $P d e 6 b^{H 620 Q}$ homozygotes, but no stronger than the $P d e 6 b^{H 620 Q} / P d e 6 b^{r d 1}$ phenotype (Hart et al., 2005). The slower rate of degeneration exhibited by $P d e 6 b^{H 620 Q} / P d e 6 b^{\text {Stop }}$ suggests some transcriptional readthrough events (Miyoshi and Fishell, 2006). Nevertheless, $P d e 6 b^{H 620 Q} / P d e 6 b^{\text {Stop }}$ mice exhibit classic rod and subsequent cone degeneration phenotype as seen in other Pde6b mutant lines (Chang et al., 2002; Hart et al., 2005; Gargini et al., 2007). As $P d e 6 b^{H 620 Q}$ and $P d e 6 b^{\text {Stop }}$ mutations were generated independently, it is unlikely the phenotypes presented here are the result homozygosity at another locus.

This new Pde6b ${ }^{H 620 Q} / P d e 6 b^{\text {Stop }}$ mouse provides several advantages. First, as a compound heterozygote, the mouse more closely resembles sporadic human cases (McLaughlin et al., 1993, 1995; Danciger et al., 1995; Tsang et al., 2008). Second, it provides a precise, highly reproducible method for generating "optimally" treated retinas, without the limitations inherent in the use of randomly integrated transgenes or subretinal trauma caused by injection of viral vectors (Deyle and Russell, 2009; Huang and Yang, 2009; Zinkernagel et al., 2011; Biasco et al., 2012; Wert et al., 2012). Third, this tool is flexible: the Stop mouse can be combined with any CreERT2 driver to readily generate retinas with specific temporal and/or special patterns of degeneration. CreERT2 is recommended, as constitutively active Cre is associated with toxicity (Hameyer et al., 2007).

Here we used the Rosa26 $6^{\text {CreERT2 }}$ driver to induce recombination in early embryonic cells and generated efficient rescue. At later times, the ability to rescue photoreceptors is incomplete, likely due to downregulation of the Rosa26 locus in the adult neural lineage (Hameyer et al., 2007). Nevertheless, Cre activity was detected in retinal photoreceptors after a double-tamoxifen treatment at P1, as demonstrated by restoration of rod photoreceptor function and Stop to-loxP allele recombination in retinal DNA. Although more efficient postnatal photoreceptor-specific CreERT2 drivers are not currently available, one can conceive of using Pde6g ${ }^{C r E E R T 2}$ or tetracycline-inducible photoreceptor drivers (Chang et al., 2000) for the purpose of fully exploiting the utility of the $P d e 6 b^{\text {Stop }}$ allele. These types of drivers will be critical for extending the study of treatments beyond early postnatal life and deeper into periods with significant degeneration, which will be the usual clinical setting for patients with RP. The stage of human RP disease that was modeled using the Rosa26 CreERT2 driver in this paper might represent the earliest possible intervention, most likely in young children, after fetal or postnatal genotyping (Kitzman et al., 2012).

Our mouse model, although not addressing the effects of surgically delivered viral vectors, does suggest two issues inherent in genetic treatment of RP. First, to provide effective gene therapy to patients, it is not clear how many macular rods have to be successfully transduced with PDE6-expressing vectors to prevent secondary loss of cones. Our results suggest that complete, partial, and incomplete restoration of retinal function depend on the number of treated photoreceptors. Not achieving a minimum number of rescued rods is likely to cause nonautonomous death of rescued rods (Kedzierski et al., 1998; Streichert et al., 1999; Delyfer et al., 2005). Because many RP patients initially present with considerable degeneration (loss of peripheral rods and cones, cases may involve of the macula as well), then early treatment may produce favorable outcomes.

Second, it is not clear which clinical parameters are most important in defining an effective treatment. Our results suggest that, even in cases of long-term functional rescue, retinal pathology may persist after treatment. Although mid-embryonic and postnatal treatment produced long-term rescue of most retinal function, we observed reductions in mixed rod-cone ERG responses, loss of photoreceptors, abnormal cone morphology, and hyper-AF spots. The significance of abnormal cone morphology is not clear, as cone amplitudes appear to be unaffected. However, partial loss of photoreceptors likely contributed to reduced mixed responses and hyper-AF, which may correspond to lysosome-laden microglial cells located between the neural retina and the retinal pigment epithelium (RPE) or abnormal accumulation of lipofuscin in the RPE (Robson et al., 2008; Xu et al., 2008; Lima et al., 2009, 2012; Wang et al., 2009; Greenstein et al., 2012). AF spots are not specific to Pde6b model (Wang et al., 2009; Sancho-Pelluz et al., 2012). With a different team of coauthors, we have a manuscript in press (Wang et al., 2013), we demonstrated that AF spots are microglial rather than of RPE origin. We imagine inefficiencies associated with subretinal surgery, viral immunogenicity, viral transduction, nonendogenous rescue gene expression, and potential vector inactivation/silencing further complicate the picture. Thus, the limits of rescue and the persistence of disease features require future investigation.

Although much progress has been made toward conducting human gene therapy for RP, it is important to continue to define emerging challenges (Stieger and Lorenz, 2010; Liu et al., 2011; Sahni et al., 2011). Indeed, the most recent report on human gene therapy indicates, despite functional rescue, photoreceptor degeneration continues to progress (Cideciyan et al., 2013). A common denominator to previous successes in modeling gene therapy in PDE6-deficient animals suggests earlier treatment in humans might be effective. However, early identification of sporadic cases may require pediatric screening or sequencing $\mathrm{RP}$ genes in fetal DNA in maternal blood (Kitzman et al., 2012). On the other hand, early treatment may further expose the limits of gene therapy, especially if "successfully treated" maculas harbor subtle signs of disease, either coincident or consequent with treatment, which may or may not progress to blindness. Thus, another viable direction may be to use a combination of gene and drug therapies to stop retinal degeneration (Tosi et al., 2011b; Trifunovic et al., 2012).

\section{References}

Allocca M, Manfredi A, Iodice C, Di Vicino U, Auricchio A (2011) AAVmediated gene replacement, either alone or in combination with physical and pharmacological agents, results in partial and transient protection from photoreceptor degeneration associated with betaPDE deficiency. Invest Ophthalmol Vis Sci 52:5713-5719. CrossRef Medline

Badea TC, Wang Y, Nathans J (2003) A noninvasive genetic/pharmacologic strategy for visualizing cell morphology and clonal relationships in the mouse. J Neurosci 23:2314-2322. Medline

Berson EL (1993) Retinitis pigmentosa: the Friedenwald lecture. Invest Ophthalmol Vis Sci 34:1659-1676. Medline

Biasco L, Baricordi C, Aiuti A (2012) Retroviral integrations in gene therapy trials. Mol Ther 20:709-716. CrossRef Medline

Bird AC (1995) Retinal photoreceptor dystrophies LI: Edward Jackson Memorial Lecture. Am J Opthalmol 119:543-562. Medline

Blanks JC, Johnson LV, Hageman GS (1993) Stage-specific binding of pea- 
nut agglutinin to aggregates of degenerating photoreceptor cells in the rd mouse retina. Exp Eye Res 57:265-273. CrossRef Medline

Brocard J, Warot X, Wendling O, Messaddeq N, Vonesch JL, Chambon P, Metzger D (1997) Spatio-temporally controlled site-specific somatic mutagenesis in the mouse. Proc Natl Acad Sci U S A 94:14559-14563. CrossRef Medline

Chang B, Hawes NL, Hurd RE, Davisson MT, Nusinowitz S, Heckenlively JR (2002) Retinal degeneration mutants in the mouse. Vision Res 42:517525. CrossRef Medline

Chang MA, Horner JW, Conklin BR, DePinho RA, Bok D, Zack DJ (2000) Tetracycline-inducible system for photoreceptor-specific gene expression. Invest Ophthalmol Vis Sci 41:4281-4287. Medline

Cideciyan AV, Jacobson SG, Beltran WA, Sumaroka A, Swider M, Iwabe S, Roman AJ, Olivares MB, Schwartz SB, Komaromy AM, Hauswirth WW, Aguirre GD (2013) Human retinal gene therapy for Leber congenital amaurosis shows advancing retinal degeneration despite enduring visual improvement. Proc Natl Acad Sci U S A 110:517-525. CrossRef Medline

Curcio CA, Owsley C, Jackson GR (2000) Spare the rods, save the cones in aging and age-related maculopathy. Invest Ophthalmol Vis Sci 41:20152018. Medline

Daiger SP, Bowne SJ, Sullivan LS (2007) Perspective on genes and mutations causing retinitis pigmentosa. Arch Ophthalmol 125:151-158. CrossRef Medline

Danciger M, Blaney J, Gao YQ, Zhao DY, Heckenlively JR, Jacobson SG, Farber DB (1995) Mutations in the PDE6B gene in autosomal recessive retinitis pigmentosa. Genomics 30:1-7. CrossRef Medline

Danielian PS, Muccino D, Rowitch DH, Michael SK, McMahon AP (1998) Modification of gene activity in mouse embryos in utero by a tamoxifeninducible form of Cre recombinase. Curr Biol 8:1323-1326. CrossRef Medline

Davis RJ, Tosi J, Janisch KM, Kasanuki JM, Wang NK, Kong J, Tsui I, Cilluffo M, Woodruff ML, Fain GL, Lin CS, Tsang SH (2008) Functional rescue of degenerating photoreceptors in mice homozygous for a hypomorphic cGMP phosphodiesterase $6 \mathrm{~b}$ allele (Pde6bH620Q). Invest Ophthalmol Vis Sci 49:5067-5076. CrossRef Medline

Delyfer MN, Forster V, Neveux N, Picaud S, Léveillard T, Sahel JA (2005) Evidence for glutamate-mediated excitotoxic mechanisms during photoreceptor degeneration in the $\mathrm{rd} 1$ mouse retina. Mol Vis 11:688-696. Medline

Deyle DR, Russell DW (2009) Adeno-associated virus vector integration. Curr Opin Mol Ther 11:442-447. Medline

Dryja TP, Berson EL (1995) Retinitis pigmentosa and allied diseases: implications of genetic heterogeneity. Invest Ophthalmol Vis Sci 36:11971200. Medline

Dryja TP, Rucinski DE, Chen SH, Berson EL (1999) Frequency of mutations in the gene encoding the alpha subunit of rod cGMP-phosphodiesterase in autosomal recessive retinitis pigmentosa. Invest Ophthalmol Vis Sci 40:1859-1865. Medline

Dvir L, Srour G, Abu-Ras R, Miller B, Shalev SA, Ben-Yosef T (2010) Autosomal-recessive early-onset retinitis pigmentosa caused by a mutation in PDE6G, the gene encoding the gamma subunit of rod cGMP phosphodiesterase. Am J Hum Genet 87:258-264. CrossRef Medline

Gargini C, Terzibasi E, Mazzoni F, Strettoi E (2007) Retinal organization in the retinal degeneration 10 (rd10) mutant mouse: a morphological and ERG study. J Comp Neurol 500:222-238. CrossRef Medline

Greenstein VC, Duncker T, Holopigian K, Carr RE, Greenberg JP, Tsang SH, Hood DC (2012) Structural and functional changes associated with normal and abnormal fundus autofluorescence in patients with retinitis pigmentosa. Retina 32:349-357. CrossRef Medline

Grüter O, Kostic C, Crippa SV, Perez MT, Zografos L, Schorderet DF, Munier FL, Arsenijevic Y (2005) Lentiviral vector-mediated gene transfer in adult mouse photoreceptors is impaired by the presence of a physical barrier. Gene Ther 12:942-947. CrossRef Medline

Hameyer D, Loonstra A, Eshkind L, Schmitt S, Antunes C, Groen A, Bindels E, Jonkers J, Krimpenfort P, Meuwissen R, Rijswijk L, Bex A, Berns A, Bockamp E (2007) Toxicity of ligand-dependent Cre recombinases and generation of a conditional Cre deleter mouse allowing mosaic recombination in peripheral tissues. Physiol Genomics 31:32-41. CrossRef Medline

Hahn LB, Berson EL, Dryja TP (1994) Evaluation of the gene encoding the G subunit of rod phosphodiesterase in retinitis pigmentosa. Invest Ophthalmol Vis Sci 35:1077-1082. Medline
Hart AW, McKie L, Morgan JE, Gautier P, West K, Jackson IJ, Cross SH (2005) Genotype-phenotype correlation of mouse pde6b mutations. Invest Ophthalmol Vis Sci 46:3443-3450. CrossRef Medline

Hartong DT, Berson EL, Dryja TP (2006) Retinitis pigmentosa. Lancet 368: 1795-1809. CrossRef Medline

Hirate J, Horikoshi I, Watanabe J, Ozeki S (1984) Effect of hypothermia and ether anesthesia on the dispositions of creatinine and urea in mice. J Pharmacobiodyn 7:883-890. CrossRef Medline

Huang SH, Pittler SJ, Huang X, Oliveira L, Berson EL, Dryja TP (1995) Autosomal recessive retinitis pigmentosa caused by mutations in the alpha subunit of rod cGMP phosphodiesterase. Nat Genet 11:468-471. CrossRef Medline

Huang X, Yang Y (2009) Innate immune recognition of viruses and viral vectors. Hum Gene Ther 20:293-301. CrossRef Medline

Jackson GR, Owsley C, Curcio CA (2002) Photoreceptor degeneration and dysfunction in aging and age-related maculopathy. Ageing Res Rev 1:381396. CrossRef Medline

Kedzierski W, Bok D, Travis GH (1998) Non-cell-autonomous photoreceptor degeneration in rds mutant mice mosaic for expression of a rescue transgene. J Neurosci 18:4076-4082. Medline

Kellendonk C, Tronche F, Casanova E, Anlag K, Opherk C, Schütz G (1999) Inducible site-specific recombination in the brain. J Mol Biol 285:175182. CrossRef Medline

Kitzman JO, Snyder MW, Ventura M, Lewis AP, Qiu R, Simmons LE, Gammill HS, Rubens CE, Santillan DA, Murray JC, Tabor HK, Bamshad MJ, Eichler EE, Shendure J (2012) Noninvasive whole-genome sequencing of a human fetus. Sci Transl Med 4:137ra176. CrossRef Medline

Klein R, Rowland ML, Harris MI (1995) Racial/ethnic differences in agerelated maculopathy: Third National Health and Nutrition Examination Survey. Ophthalmology 102:371-381. Medline

Klein R, Klein BE, Jensen SC, Mares-Perlman JA, Cruickshanks KJ, Palta M (1999) Age-related maculopathy in a multiracial United States population: The National Health and Nutrition Examination Survey III. Ophthalmology 106:1056-1065. CrossRef Medline

Lakso M, Sauer B, Mosinger B Jr, Lee EJ, Manning RW, Yu SH, Mulder KL, Westphal H (1992) Targeted oncogene activation by site-specific recombination in transgenic mice. Proc Natl Acad Sci U S A 89:6232-6236. CrossRef Medline

Lee EC, Yu D, Martinez de Velasco J, Tessarollo L, Swing DA, Court DL, Jenkins NA, Copeland NG (2001) A highly efficient Escherichia colibased chromosome engineering system adapted for recombinogenic targeting and subcloning of BAC DNA. Genomics 73:56-65. CrossRef Medline

Lima LH, Cella W, Greenstein VC, Wang NK, Busuioc M, Smith RT, Yannuzzi LA, Tsang SH (2009) Structural assessment of hyperautofluorescent ring in patients with retinitis pigmentosa. Retina 29:1025-1031. CrossRef Medline

Lima LH, Burke T, Greenstein VC, Chou CL, Cella W, Yannuzzi LA, Tsang SH (2012) Progressive constriction of the hyperautofluorescent ring in retinitis pigmentosa. Am J Ophthalmol 153:718-727, 727 e1-2. CrossRef Medline

Liu MM, Tuo J, Chan CC (2011) Gene therapy for ocular diseases. Br J Ophthalmol 95:604-612. CrossRef Medline

McCarrick JW 3rd, Parnes JR, Seong RH, Solter D, Knowles BB (1993) Positive-negative selection gene targeting with the diphtheria toxin A-chain gene in mouse embryonic stem cells. Transgenic Res 2:183-190. CrossRef Medline

McLaughlin ME, Sandberg MA, Berson EL, Dryja TP (1993) Recessive mutations in the gene encoding the b-subunit of rod phosphodiesterase in patients with retinitis pigmentosa. Nat Genet 4:130-134. CrossRef Medline

McLaughlin ME, Ehrhart TL, Berson EL, Dryja TP (1995) Mutation spectrum of the gene encoding the $b$ subunit of rod phosphodiesterase among patients with autosomal recessive retinitis pigmentosa. Proc Natl Acad Sci U S A 92:3249-3253. CrossRef Medline

Mitamura Y, Mitamura-Aizawa S, Nagasawa T, Katome T, Eguchi H, Naito T (2012) Diagnostic imaging in patients with retinitis pigmentosa. J Med Invest 59:1-11. CrossRef Medline

Miyoshi G, Fishell G (2006) Directing neuron-specific transgene expression in the mouse CNS. Curr Opin Neurobiol 16:577-584. CrossRef Medline

Owsley C, Jackson GR, Cideciyan AV, Huang Y, Fine SL, Ho AC, Maguire MG, Lolley V, Jacobson SG (2000) Psychophysical evidence for rod vul- 
nerability in age-related macular degeneration. Invest Ophthalmol Vis Sci 41:267-273. Medline

Owsley C, Jackson GR, White M, Feist R, Edwards D (2001) Delays in rodmediated dark adaptation in early age-related maculopathy. Ophthalmology 108:1196-1202. CrossRef Medline

Pang JJ, Dai X, Boye SE, Barone I, Boye SL, Mao S, Everhart D, Dinculescu A, Liu L, Umino Y, Lei B, Chang B, Barlow R, Strettoi E, Hauswirth WW (2011) Long-term retinal function and structure rescue using capsid mutant AAV8 vector in the rd10 mouse, a model of recessive retinitis pigmentosa. Mol Ther 19:234-242. CrossRef Medline

Pang JJ, Boye SL, Deng W, Kumar A, Dinculescu A, Chiodo V, Li J, Li Q, Rani A, Foster TC, Chang B, Hawes NL, Boatright JH, Hauswirth WW (2008) $\mathrm{AAV}$-mediated gene therapy delays retinal degeneration in the $\mathrm{rd} 10$ mouse containing a recessive PDEbeta mutation. Invest Ophthalmol Vis Sci 49:4278-4283. CrossRef Medline

Petit L, Lhériteau E, Weber M, Le Meur G, Deschamps JY, Provost N, Mendes-Madeira A, Libeau L, Guihal C, Colle MA, Moullier P, Rolling F (2012) Restoration of vision in the pde6beta-deficient dog, a large animal model of rod-cone dystrophy. Mol Ther 20:2019-2030. CrossRef Medline

Petrs-Silva H, Dinculescu A, Li Q, Min SH, Chiodo V, Pang JJ, Zhong L, Zolotukhin S, Srivastava A, Lewin AS, Hauswirth WW (2009) Highefficiency transduction of the mouse retina by tyrosine-mutant AAV serotype vectors. Mol Ther 17:463-471. CrossRef Medline

Robson AG, Michaelides M, Saihan Z, Bird AC, Webster AR, Moore AT, Fitzke FW, Holder GE (2008) Functional characteristics of patients with retinal dystrophy that manifest abnormal parafoveal annuli of high density fundus autofluorescence: a review and update. Doc Ophthalmol 116: 79-89. CrossRef Medline

Sahni JN, Angi M, Irigoyen C, Semeraro F, Romano MR, Parmeggiani F (2011) Therapeutic challenges to retinitis pigmentosa: from neuroprotection to gene therapy. Curr Genomics 12:276-284. CrossRef Medline

Sancho-Pelluz J, Tosi J, Hsu CW, Lee F, Wolpert K, Tabacaru MR, Greenberg JP, Tsang SH, Lin CS (2012) Mice with a D190N mutation in the gene encoding rhodopsin: a model for human autosomal-dominant retinitis pigmentosa. Mol Med 18:549-555. CrossRef Medline

Silva M, Gras J (1979) [conditions for greater survival of neonatally thymectomized Swiss mice (author's transl)]. Rev Esp Fisiol 35:85-87. Medline

Sparrow JR, Blonska A, Flynn E, Duncker T, Greenberg JP, Secondi R, Ueda K, Delori FC (2013) Quantitative fundus autofluorescence in mice: correlation with HPLC quantitation of RPE lipofuscin and measurement of retina outer nuclear layer thickness. Invest Ophthalmol Vis Sci 54:2812-2820. CrossRef Medline

Stieger K, Lorenz B (2010) Gene therapy for vision loss: recent developments. Discov Med 10:425-433. Medline

Streichert LC, Birnbach CD, Reh TA (1999) A diffusible factor from normal retinal cells promotes rod photoreceptor survival in an in vitro model of retinitis pigmentosa. J Neurobiol 39:475-490. CrossRef Medline
Suckow MA, Stevens KA, Wilson RP (2012) The laboratory rabbit, guinea pig, hamster, and other rodents, Ed 1. Waltham, MA: Academic.

Tawara A, Varner HH, Hollyfield JG (1989) Proteoglycans in the mouse interphotoreceptor matrix: II. Origin and development of proteoglycans. Exp Eye Res 48:815-839. CrossRef Medline

Tosi J, Davis RJ, Wang NK, Naumann M, Lin CS, Tsang SH (2011a) shRNA knockdown of guanylate cyclase $2 \mathrm{e}$ or cyclic nucleotide gated channel alpha 1 increases photoreceptor survival in a cGMP phosphodiesterase mouse model of retinitis pigmentosa. J Cell Mol Med 15:1778-1787. CrossRef Medline

Tosi J, Sancho-Pelluz J, Davis RJ, Hsu CW, Wolpert KV, Sengillo JD, Lin CS, Tsang SH (2011b) Lentivirus-mediated expression of cDNA and shRNA slows degeneration in retinitis pigmentosa. Exp Biol Med (Maywood) 236:1211-1217. CrossRef Medline

Trifunović D, Sahaboglu A, Kaur J, Mencl S, Zrenner E, Ueffing M, ArangoGonzalez B, Paquet-Durand F (2012) Neuroprotective strategies for the treatment of inherited photoreceptor degeneration. Curr Mol Med 12: 598-612. CrossRef Medline

Tsang SH, Gouras P, Yamashita CK, Kjeldbye H, Fisher J, Farber DB, Goff SP (1996) Retinal degeneration in mice lacking the gamma subunit of the rod cGMP phosphodiesterase. Science 272:1026-1029. CrossRef Medline

Tsang SH, Tsui I, Chou CL, Zernant J, Haamer E, Iranmanesh R, Tosi J, Allikmets R (2008) A novel mutation and phenotypes in phosphodiesterase 6 deficiency. Am J Ophthalmol 146:780-788. CrossRef Medline

Tsui I, Song B, Lin CS, Tsang S (2007) A practical approach to retinal dystrophies. Retin Physician 4:18-26.

Wang NK, Fine HF, Chang S, Chou CL, Cella W, Tosi J, Lin CS, Nagasaki T, Tsang SH (2009) Cellular origin of fundus autofluorescence in patients and mice with a defective NR2E3 gene. Br J Ophthalmol 93:1234-1240. CrossRef Medline

Wang NK, Lai CC, Liu CH, Yeh LK, Chou CL, Kong J, Nagasaki T, Tsang SH, Chien CL (2013) Origin of fundus hyperautofluorescent spots, and their role in retinal degeneration in a mouse model of Goldmann-Favre syndrome. Dis Model Mech, in press. CrossRef Medline

Wert KJ, Skeie JM, Davis RJ, Tsang SH, Mahajan VB (2012) Subretinal injection of gene therapy vectors and stem cells in the perinatal mouse eye. J Vis Exp 69:4286. CrossRef Medline

Wert KJ, Davis RJ, Sancho-Pelluz J, Nishina PM, Tsang SH (2013) Gene therapy provides long-term visual function in a preclinical model of retinitis pigmentosa. Hum Mol Genet 22:558-567. CrossRef Medline

Xu H, Chen M, Manivannan A, Lois N, Forrester JV (2008) Age-dependent accumulation of lipofuscin in perivascular and subretinal microglia in experimental mice. Aging Cell 7:58-68. CrossRef Medline

Zinkernagel MS, McMenamin PG, Forrester JV, Degli-Esposti MA (2011) T cell responses in experimental viral retinitis: mechanisms, peculiarities and implications for gene therapy with viral vectors. Prog Retin Eye Res 30:275-284. CrossRef Medline 